lirAs Extronsion

\title{
Tropical Soda Apple: Biology, Ecology and Management of a Noxious Weed in Florida ${ }^{1}$
}

\section{Brent Sellers, Jay Ferrell, J. Jeffrey Mullahey, and Pat Hogue ${ }^{2}$}

Tropical soda apple (Solanum viarum Dunal) is a serious weed problem in many perennial grass pastures and native areas of Florida. With foliage unpalatable to livestock, this invasive weed can infest a pasture in as little as one to two years, resulting in reduced forage production and lower stocking rates.

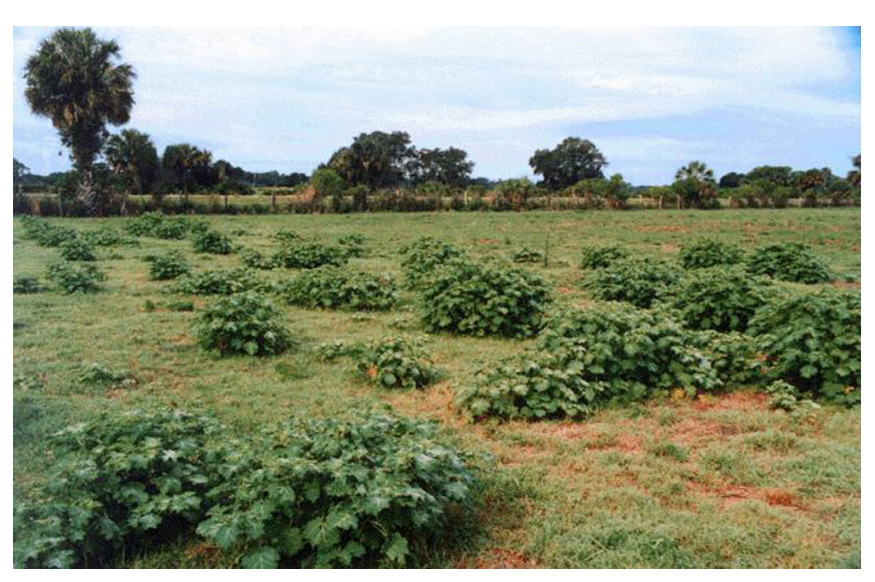

Figure 1. Tropical soda apple in a typical south Florida bahiagrass pasture.
Geographically, the incidence of this weed in Florida has been highest in South Florida although the plant is now commonly observed throughout the state. Tropical soda apple (TSA) is a common weed in pastures, ditch banks, citrus groves, sugarcane fields, and rangeland. The plant appears to be restricted to semi-disturbed sites. The highest incidence of TSA has occurred in improved pastures, such as bahiagrass, with an estimated 1 million acres infested in Florida.

This invasive weed produces a yellow fruit when mature (1-1.5 inches in diameter), which contains 200-400 seeds per fruit. Little or no seed dormancy has been observed, and germination is generally greater than 75 percent. The plant is readily identified by its immature fruit, which are green with white mottling, similar to watermelon. Fruit production occurs throughout the year, but mostly from September through May, thus providing 40,000-50,000 viable seeds per plant per year. Wildlife -- such as feral hogs, raccoons, and deer --

1. This document is SS-AGR-77, one of a series of the Agronomy Department, Florida Cooperative Extension Service, Institute of Food and Agricultural Sciences, University of Florida. Originally published October 1993 as WEC-7. Revised August 2006. Reviewed November 2006. Revised February 2009. Visit the EDIS Web site at http://edis.ifas.ufl.edu.

2. Brent Sellers, assistant professor, Agronomy Department, Range Cattle Research and Education Center -- Ona, FL; Jay Ferrell, assistant professor, Agronomy Department, Gainesville, FL; J. Jeffrey Mullahey, professor, Wildlife Ecology and Conservation Department, and director, West Florida Research and Education Center -- Milton, FL; and Pat Hogue, extension agent III, Okeechobee County, Okeechobee, FL, Institute of Food and Agricultural Sciences, University of Florida.

The use of trade names in this publication is solely for the purpose of providing specific information. UF/IFAS does not guarantee or warranty the products named, and references to them in this publication does not signify our approval to the exclusion of other products of suitable composition. All chemicals should be used in accordance with directions on the manufacturer's label.

The Institute of Food and Agricultural Sciences (IFAS) is an Equal Opportunity Institution authorized to provide research, educational information and other services only to individuals and institutions that function with non-discrimination with respect to race, creed, color, religion, age, disability, sex, sexual orientation, marital status, national origin, political opinions or affiliations. U.S. Department of Agriculture, Cooperative Extension Service, University of Florida, IFAS, Florida A. \& M. University Cooperative Extension Program, and Boards of County Commissioners Cooperating. Interim Dean Millie Ferrer 
feed on the fruit and are vectors for spreading seed through their feces. Cattle will also consume the fruit and spread the seed in this way.

\section{Weed Taxonomy}

At maturity, TSA is 3-6 feet tall. Stems, leaves, flower-stalks and calyxes have broad-based, white-to-yellowing thorns up to 0.4 inches long. Pubescent leaves are 4-7 inches long and 2-6 inches wide, deeply divided into broad, pointed lobes. Flowers are white with yellow stamens, a few together on stems below the leaves. Fruits are glabrous, globular, about 1 inch in diameter, yellow when mature. Seeds are light red-brown, 0.10 inches in diameter. Seeds are only moderately flattened, contained in a mucilaginous layer that contains a glyco-alkaloid called solasodine.

\section{Weed Biology}

Tropical soda apple flowers throughout the year although flowering is concentrated from September through May. Fruit production is also yearly, and a mature plant will commonly have both immature (green fruit) and mature (yellow) fruit. Seed germination from green fruit is often similar to that of yellow fruit. Seed that is white in color is not viable, regardless of fruit color.

Seedling emergence primarily occurs during the dry season (October through May). New plants will emerge either from seed or from perennial roots. Roots have buds that regenerate new shoots. The root system can be extensive, with feeder roots (0.25-01.0 inch diameter) located a few inches below the ground and extending 3-6 feet from the crown of the plant.

Seed germination has occurred from seed planted 3.25 inches into the ground. It is not known how deep TSA seed may be placed in the soil before

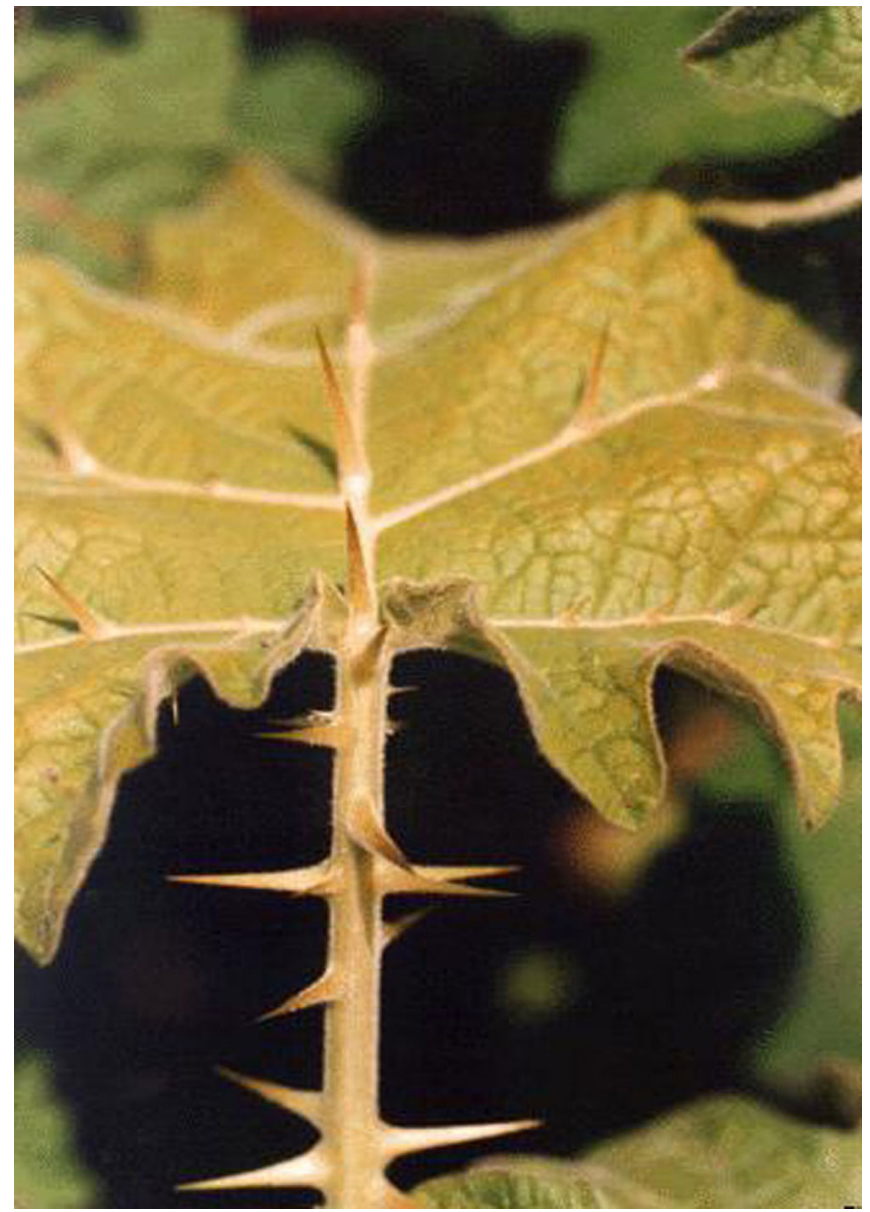

Figure 2. Thorn-like prickles on a tropical soda apple leaf.

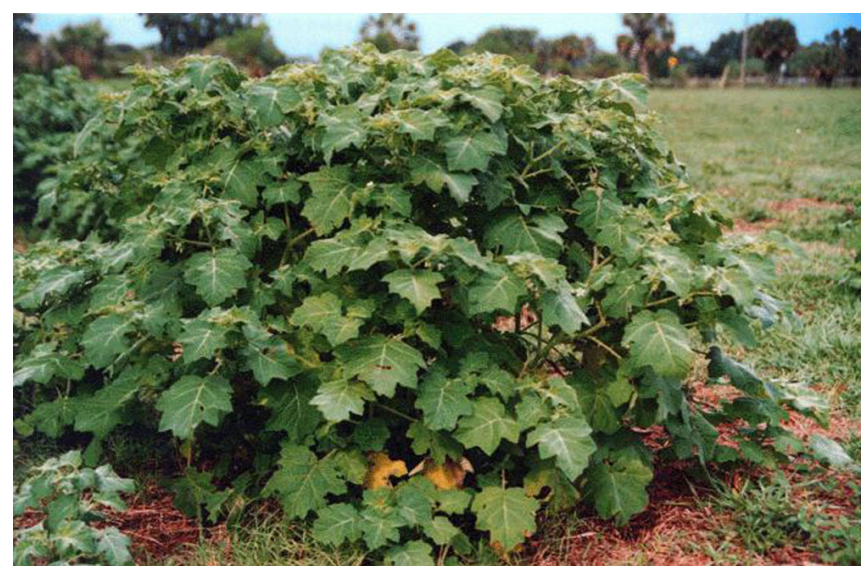

Figure 3. Mature tropical soda apple plant.

germination is inhibited. However, preliminary evidence suggests that seeds of this plant that are buried 6 inches deep will not germinate until they are brought back to the soil surface. Seed germination is dependent upon temperature, light, and age of seed. Under laboratory conditions, seed germination was highest (95 percent) for 5-month-old seed, followed by a gradual decline to zero germination at 25 months. Under field conditions, preliminary evidence suggests 


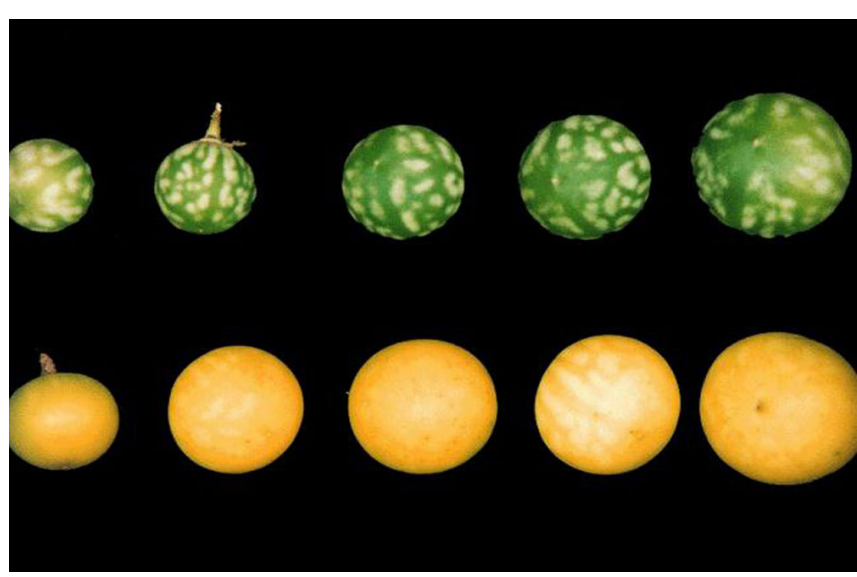

Figure 4. Tropical soda apple fruit. Top row: immature fruit. Bottom row: mature fruit.

that buried seed may survive longer than seed that are left on the soil surface.

\section{Weed Ecology}

Tropical soda apple is a common weed in South America, India, West Indies, Honduras, and Mexico. The plant is native to Argentina and central Brazil and has been introduced in Africa and Nepal. Tropical soda apple can be expected to occur in other subtropical areas, as well.

In Florida, TSA has been observed as a common weed in pastures, ditch banks, citrus groves, sugarcane fields, and wet areas of rangeland. In South Florida, TSA is typically found on seasonally wet soils. During extended periods (more than three weeks) of standing water, TSA plant death can occur. In ideal conditions, TSA was once commonly found growing as a monoculture covering up to 50 acres or more. Currently, monocultures of 50 acres or more are typically rare, but monocultures of TSA are common in feeding and lounging areas within pastures.

Solanum sp. were first reported by ranchers in South Florida in the early 1960s. However, these initial reports indicated the fruit was a cherry-red color, now yellow. Apparently, ranchers were observing Solanum capsicoides (Figure 5), not TSA. For the past 15-20 years in South Florida, TSA has been the most prevalent of those two species.

Reasons for the increase in TSA are not well understood. Although there have been reported cases of severe leaf defoliation of TSA caused by Colorado

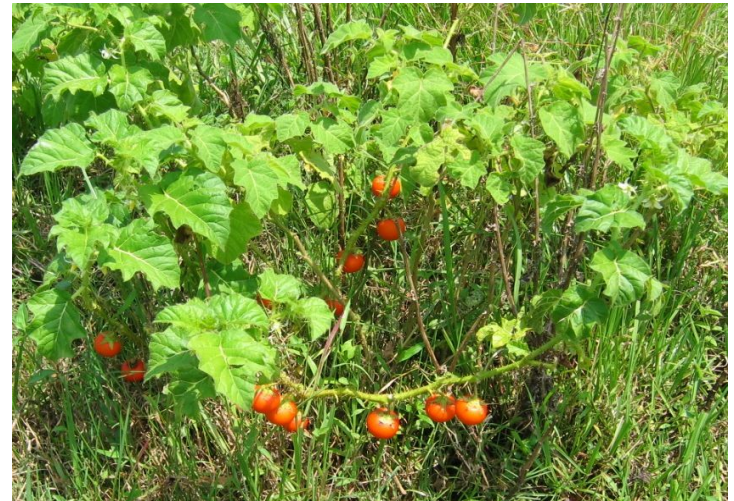

Figure 5. Solanum capsicoides, commonly known as cockroach berry or red soda apple, is often mistaken for TSA. However, Solanum capsicoides is not as common.

potato beetle, as well as the released biocontrol agent Gratiana boliviana (commonly referred to as the TSA beetle), death of TSA plants due to defoliation is rare. Occasionally, TSA plants appear stressed and display symptoms of leaf mottling, inclusions, etc., associated with fungi or bacteria.

\section{Chemical Control}

Dense infestations. Milestone and Forefront herbicides are the most effective for controlling dense stands of TSA. These herbicides possess postemergence control of existing plants and preemergence control of germinating seeds. Our research has shown that Milestone and Forefront will control germinating seedlings for more than six months after application.

The application rate for Milestone is 5-7 oz/A. The rate for Forefront is 2-2.6 pt/A. Although the lower application rates are highly effective on existing TSA plants, the higher rates suggested for these two herbicides will provide more soil activity and are suggested if large amounts of TSA seed are present in the soil. Although mowing prior to herbicide application is not required, it is important to add a non-ionic surfactant $(0.25 \% \mathrm{v} / \mathrm{v})$ and apply the herbicide solution in at least 20 gallons of water per acre.

Another option is to use the herbicide, Remedy. When using Remedy, mow plants to a 3-inch stubble height as soon as possible to keep plants from producing fruit and seed. Repeat mowing when plants reach the flowering stage (50-60 days) through April. Fifty to 60 days after the April mowing, when plant 
regrowth is at the first flower stage (late May-June), spray Remedy at $1 \mathrm{qt} / \mathrm{A}+0.25 \% \mathrm{v} / \mathrm{v}$ non-ionic surfactant in $40 \mathrm{gal} / \mathrm{A}$ of water. Remedy does not possess soil residual activity, and follow-up applications to control escaped or new seedlings will be necessary.

Regardless which herbicide is used, regular scouting after treatment is necessary. Tropical soda apple can produce fruit at almost any time during the growing season and give rise to hundreds of additional plants. It is important to monitor the fields to ensure that no plants are allowed to reestablish and produce fruit.

Sparse infestations. Areas with low TSA infestation should be targeted, and each plant sprayed individually. Recommended herbicides for 95-100 percent control are as follows:

1. Milestone at $0.5-0.8 \mathrm{oz}$ per $2.5 \mathrm{gal}$ ( 15 to $20 \mathrm{ml}$ per $2.5 \mathrm{gal})+0.25 \% \mathrm{v} / \mathrm{v}$ non-ionic surfactant + color marker. (Use a color marker with the herbicide solution to avoid spraying the same plant twice or not spraying a plant at all).

2. Forefront or Remedy at 0.5 percent solution (50 $\mathrm{ml}$ per $2.5 \mathrm{gal})+0.25$ percent non-ionic surfactant + color marker.

When spot-spraying, cover the entire plant with spray solution to ensure herbicide uptake and maximum control. Allow herbicides to dry on plants three to four hours before rainfall. Monitor treated areas monthly, and treat new TSA seedlings. Do not allow plants to produce fruit. Be sure to follow the guidelines for spraying volatile herbicides such as Remedy. (For more information, see EDIS publication SS-AGR-12, Floridas Organo-Auxin Herbicide Rule, http://edis.ifas.ufl.edu/WG051.)

\section{Biological Control}

Biological herbicide. A natural, biological herbicide to control TSA is currently under development and is not available for public use at this time. The product is called SolviNix ${ }^{\mathrm{TM}}$ and contains a naturally occurring virus called Tobacco mild green mosaic tobamovirus (TMGMV). Preliminary research has determined that very small quantities of the virus ( $2 \mathrm{~g}$ of active ingredient per acre) provide excellent control of TSA. Two application methods are currently being tested that appear to be practical and user friendly for both boom spraying and spot-spraying. For more information on SolviNix, see the TSA Web site, tsa.ifas.ufl.edu.

TSA beetle. A beetle known as Gratiana boliviana (TSA beetle) has been investigated over the past several years for the control of TSA plants. This beetle is native to South America and underwent a rigorous quarantine process prior to its release in 2003. Host-specificity tests were conducted in both the U.S. and in South America; the tests proved that this beetle is highly specific to TSA. For more detailed information on the TSA beetle, see EDIS Publication ENY-826 (Biology of Gratiana boliviana, the First Biocontrol Agent Released to Control Tropical Soda Apple in the USA (http://edis.ifas.ufl.edu/IN487) and EDIS Publication ENY-824 (Classical Biological Control of Tropical Soda Apple in the USA (http://eids.ifas.ufl.edu/in457).

The TSA beetle, unless present at very high populations, does not control individual plants. However, this beetle does reduce the overall fitness of the plant, making the plant less competitive with other plants. The beetle also reduces the number of fruit formed by the TSA plant. Therefore, the beetle would not be suited for controlling large populations of TSA, but is appropriate for small infestations or where TSA is present in remote areas.

For sparse stands, release 100-300 beetles and monitor the beetle population to ensure that it has become established. For dense TSA stands, release 300-500 beetles and monitor to ensure that the population persists. Once released, the beetles will reproduce and spread throughout the TSA-infested area. Whether TSA stands treated with this biological-control agent are sparse or dense, however, it is likely the TSA will rebound during the winter months (particularly during winters with no hard freezes). The TSA beetle goes through a period of diapause during winter months and will not feed on leaf tissue or reproduce during that period. Monitor the effectiveness of these beetles as they have many natural enemies. 
To obtain TSA beetles, call the Florida

Department of Agriculture and Consumer Services at (888) 397-1517 or contact your local extension agent.

\section{Management to Prevent the Spread of TSA}

Because populations of TSA continue to increase in the southeastern United States, it is imperative to continue to prevent the spread of TSA within and across the Florida border. Although the movement of TSA seed by wildlife cannot be prevented, movement of this seed can be limited in some ways. One way to prevent the movement of TSA seed is to clean off all equipment when leaving a pasture or area that is infested with TSA. Be sure to clean vehicles, mowers, tractors, and shoes.

Cattle can also transport TSA seeds. Therefore, it is important to ship cattle from an area that does not have TSA or is TSA-fruit free. Mowing a TSA-infested pasture prior to shipping will eliminate the fruit and the consumption of TSA seed by the cattle. The TSA seed can remain viable in the digestive tract for up to six days. Therefore, when you buy cattle, hold them in one area for up to six days to avoid the spread of TSA to other areas on your ranch.

\section{Further Information}

Ferrell, J.A., B. Sellers and J.J. Mullahey. 2006 and 2008. EDIS Publication SS-AGR-129, Tropical Soda Apple Control: Sorting Through the Options, http://edis.ifas.ufl.edu/AG261. Agronomy Department, University of Florida, Gainesville, FL.

Ferrell, Jason and Brent Sellers. 2007. EDIS Publication SS-AGR-262, Recommendations for Spot-Spray Treatment of Tropical Soda Apple with Milestone, http://edis.ifas.ufl.edu/AG270. Agronomy Department, University of Florida, Gainesville, FL.

Sellers, B.A. and J.A. Ferrell. 2008. EDIS Publication SS-AGR-300, Tank-mix Options for Control of Tropical Soda Apple and Dogfennel, http://edis.ifas.ufl.edu/AG306. Agronomy Department, University of Florida, Gainesville, FL.

Medal, J, W. Overholt et al. 2002 and 2006. EDIS Publication ENY-824, Classical Biological
Control of Tropical Soda Apple in the USA, http://edis.ifas.ufl.edu/IN457. Entomology and Nematology Department, University of Florida, Gainesville, FL.

Medal, J.C., D. Gandolfo et al. 2003 and 2007. ENY-826 Biology of Gratiana boliviana, the First Biocontrol Agent Released to Control Tropical Soda Apple in the USA, http://edis.ifas.ufl.edu/IN487. Entomology and Nematology Department, University of Florida, Gainesville, FL.

\section{Online publications available from the West} Florida Research and Education Center - Milton, FL.

Tropical Soda Apple, http://tsa.ifas.ufl.edu

Tropical Soda Apple Best Management Practices:

North Florida, http://tsa.ifas.ufl.edu/00Slides/NorthFlorida/ index.html

South Florida, http://tsa.ifas.ufl.edu/00Slides/SouthFlorida/ index.html 